Ethiopian Journal of Environmental Studies \& Management 9(6): 769 - 779, 2016.

ISSN:1998-0507

doi: http://dx.doi.org/10.4314/ejesm.v9i6.9

Submitted: August 05, 2016

Accepted: November 08, 2016

\title{
INTEGRATED SOLID WASTE MANAGEMENT: A PALLIATIVE TO EXISTING WASTE MANAGEMENT CHALLENGES IN JABI-DISTRICT, ABUJA
}

*MATON, D.J., KIGUN, P.A. AND OGALLA, M.

Nigerian Building and Road Research Institute, Abuja, Nigeria

\begin{abstract}
Effective solid waste management is the collective responsibility of a nation's citizens and its government. For a sustainable built-environment, urban infrastructure will need to better meet the prevailing challenges of city environments with respect to: energy and water scarcity; pollution and emissions; traffic congestion; crime; waste disposal; and safety risks from ageing infrastructure. As a concept, Integrated Solid Waste Management (ISWM) is a sustainable practice underpinned by an increased capacity for material recovery from solid waste. However, an effective ISWM depends largely on the perspective of consumers on waste generation, collection and disposal. This survey is a qualitative appraisal of solid waste management practice in Jabi district of Abuja, Nigeria's capital city, against the backdrop of solid waste best practices. The survey tools used were literature reviews, structured questionnaires, oral interviews/ focus group discussion and observation of the case study area over a one-year period. Questionnaire responses indicated that a waste collection routine by service providers exists and that the frequency of evacuation depended on the quantity of household waste generated. Survey results also indicated the following challenges to effective solid waste management in the case study area; non-sorting and bagging of waste at collection stage; poor/ inadequate infrastructure and machinery; a relaxed enforcement of the provisions of the ratified environmental regulations, etc. Possible solutions and recommendations toward a more sustainable built environment for Jabi are also proffered in accordance with global best practices.
\end{abstract}

Key Words: Solid waste management, Urbanization, ISWM, Non-sorting, Best practices

\section{Introduction}

The cities of third world countries are growing at very rapid rates compared to those in the developed nations. A UNHabitat report observed that Africa is the fastest urbanizing continent having cities like Cairo, Lagos, Nairobi, Kinshasa amongst others, growing at fast rates that would make them triple their current sizes by the year 2050 (UN Habitat, 2010). Such high rates of city-growth cause an undue stretch on the available infrastructure in urban centers resulting in the proliferation of urban slums. The increasing growth of cities, therefore, has implications for municipal solid waste 
management among other social services required in urban communities. As a result of these, the cities are often littered with 'mountains' of garbage which are eventually conveyed to landfills and/ or open fields. In some cases, the dumpsites are illegal waste dumps, which may not have been designated by government authorities. The level of environmental sanitation in Jabi- Abuja is considered as a case study on solid waste management. This problem is worsened by two factors: first, the attitudinal problem of households in this community; and secondly, poor operational approach on the side of government and also the private sector driven approach to solid waste management in the community.

\section{Background of the Study}

The perennial challenge of solid waste management in most urban centres in Nigeria requires prompt effort aimed at mitigating the effect of these waste on the environment and on humans. According to Adewuyi et al., (2009) as cited by Abila and Kantola (2013), the continuous indiscriminate disposal of municipal solid waste is on the increase and it is linked to poverty, poor governance, urbanization, population growth, poor standards of living and low levels of environmental awareness. One major challenge is to effective management of waste is the mixed-collection of waste generated from households and the eventual disposal of same as evident in this study, is corroborated by Mshelia (2015) where he opined that solid wastes are generally very diverse and usually made up of complex mixtures of biodegradable and non-biodegradable matters. It is believed to have a direct impact on humans, plants and animals and an increasing contribution to climate change.
Various methods of intervention with regards to solid waste generation and disposal have been proffered in municipalities to ameliorate the trend of lingering solid waste on our streetscapes and/or the indiscriminate dumping of wastes with very little (if any) success recorded. These interventions have come at very high costs, as can be affirmed by Agbesola (2013) investigation which indicates that a significant portion of municipal expenses (up to $40 \%$ ) goes into the provision of Solid Waste Management services in developing countries, making it one of the singly expensive sectors. Furthermore, UNHABITAT (2010), cited in Wahab (2012), quoted the chairman of Nigeria's House of

Representative's Commission on Environment as saying: "Unhealthy and poor environment costs the federal government of Nigeria a whopping 10 billion naira annually. A World Bank report puts the environment cost of Water contamination from improper waste disposal at 10 billion naira each year and the lives of about 40 million Nigerians [as] being at risk". He added that "municipal waste [remains] the most visible and Grave environmental problem, especially in urban areas".

Paradoxically, the expenses are not commensurate with the services rendered as they remain poor and ineffective. This is because effective solid waste management requires a concerted and sustained effort which though capital intensive, has the potential for economic, environmental and health benefits to the populace.

\section{Research Questions}

This research sought to answer the following questions: 
What are the challenges to effective solid waste management in Jabi district of Abuja?

* How efficient are the solid waste collection agencies in carrying out their functions of evacuating solid waste from the study area?

* How can these solid waste management practices be improved in the study area and Abuja at large?

\section{Aim and Objectives}

This research work aimed to assess the critical challenges to solid waste management in the study area through the following objectives:

* To critically assess solid waste generation, collection and disposal practices by households in the study area;

* To investigate the awareness of households on the effect of solid waste on their health and the environment;

* To assess the efficiency and effectiveness of Government's commitment towards a holistic solid waste management practice.

\section{Conceptual and Theoretical Framework}

This study attempts to explain some of the basic concepts and theories behind solid waste management. These include environment, environmental security, waste, solid waste disposal, globalization, etc. The findings from the study explain how the various concepts are used in the course of the study as against their general usage. To begin with, what do we mean when we talk about the environment and how is the concept used in this study? By environment, the study refers to all of the external factors affecting an organism. It could also mean all the circumstances, people, things, and events around an organism, a person, a community, etc that influence an organism's life. These factors or circumstances may be other living organisms (biotic factors) or nonliving variables (abiotic factors), such as temperature, rainfall and wind. The interactions of organisms, people, societies, etc with biotic and abiotic factors form what is referred to as an ecosystem, a community, an environment, etc. Having examined environment as a concept, what then is environmental security? Environmental security includes any action or a sequence of events that threatens drastically and over a relatively brief span of time to degrade the quality of life for the inhabitants. Environmental security therefore covers a wide range of issues than was generally thought. Everywhere human beings are living, solid wastes are being generated.

\section{Definition of Key Concepts}

Solid waste can be defined as nonliquid and non-gaseous products of human activities, regards as being useless. It could take the form of refuse, garbage and Sludge (Leton and Omotosho, 2004);

Solid waste generation include all discards from homes and businesses as well as wastes from manufacturing, construction and environmental cleanups. Cities in Nigeria, being among the fast growing cities in the world are all faced with the problem of solid waste generation (Onibokun and Kumuyi, 1996).

Integrated waste management is a system of waste disposal that includes separating materials according to type, and finding the best used for discarded products, which may or may not include depositing them in a landfill. The 
consequences are dire, when a country is rapidly urbanizing and its wastes are not efficiently managed. Of the different categories of wastes being generated, solid waste had posed a hydra-headed problem beyond the scope of various solid waste management systems in Nigeria (Geoffrey, 2005) as the streets experience continuous presence of solid waste from commercial activities. The quantity and generation rate of solid waste in Nigeria have increased over years without a commensurate modern technology for the efficient management of such waste. Abel's (2009) study indicated that education, income and also socio-economic status are important factors influencing per-capita solid waste generation.

\section{Study Area}

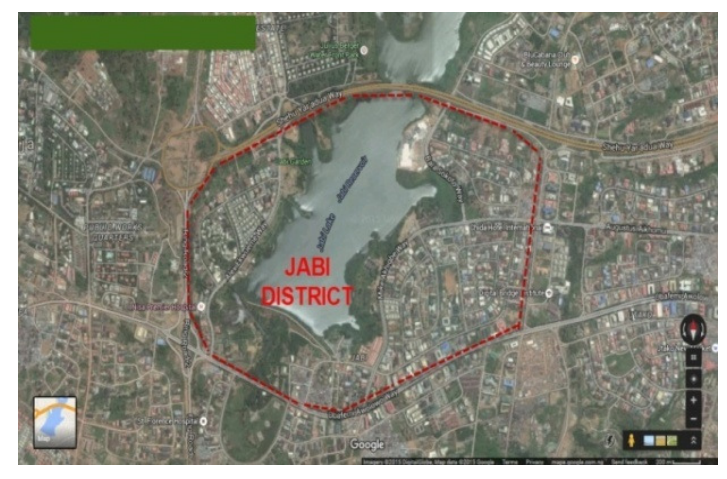

Figure 1: Jabi District, Abuja-Nigeria

(Source: Google Map)

\section{Methodology \\ Data Collection}

In examining the impact of solid waste in the study area, a survey approach was adopted and data was collected through primary and secondary sources. These consisted of but not limited to the following: Site visits and
Abuja is Nigeria's capital city. It is located in central Nigeria and boasts of being home to all federal government Ministries, Parastatal, Corporate headquarters of corporations. Besides, Abuja has an international airport and is linked to other cities in Nigeria by a network of highways. Its population, based on the 1999 estimate, is put at 403,000 people. According to the master plan, Abuja is divided into three phases. The five areas covered by the Phase I include Central, Garki, Wuse, Maitama, and Asokoro. In the Phase 2, we have areas such as Kado, Durumi, Gudu, Utako and Jabi, the survey area. In the Phase 3, the areas covered are Mabushi, Katampe, Wuye and Gwarimpa. There are also five sub-urban districts, namely Nyanyan, Karu, Gwagwalada, Kubwa, and Jikwoyi.

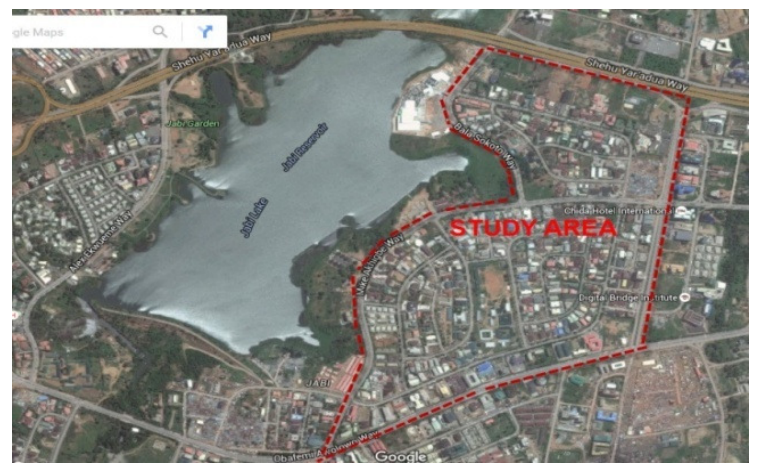

Figure 2: Survey Area Showing $2 \mathrm{Km}$ Radius from the Median

observation, questionnaire administration as well as focus group discussion with residents of the community; Mapping the area to cover a $2 \mathrm{~km}$ radius from a georeferenced midpoint using acquired satellite imagery downloaded from Google-earth; The mapped-out area was further divided into five clusters made up 
of between 25 to 50 households each, for questionnaire administration. These clusters traversed Obafemi Awolowo Way, Mike Akhigbe Street, Ebitu Ukiwe, Patrick Bokkor Crescent, Ahmed Musa Crescent and Samuel Ogedengbe Crescent, etc;

A systematic random and stratified sampling technique was applied in the selection of residents (respondents) for questionnaire administration; A total of 250 questionnaires were administered randomly to households of the 5 clusters carved out of which 213 questionnaires were retrieved and analyzed. Waste collection bags of 160 gauge polythene (i.e 40 microns or $0.4 \mathrm{~mm}$ thick) were distributed at random to households to measure the rate of waste generation and also the time taken to fill the bags before disposal at the public dumpsters; A number of 'bucket type' public dumpsters were identified and selected to buttress the severity of lingering waste awaiting collection by service providers;

The structured questionnaire for this study was design with the primary aim of: Obtaining information from Agencies responsible for waste management in the area; obtaining information from households in the area on methods of solid waste disposal and the challenges faced; obtaining information from community heads or their representatives and other stakeholders on their level of satisfaction with waste management practices in the community.

In analyzing and presentation of the survey work, descriptive and analytical methods were employed in analyzing the data by the group members. Based on this, lucid explanatory photographs were adopted all through this report.

\section{Results and Discussion}

The survey findings are as presented below under the following sub-headings:

\section{Occupancy Ratio}

The residential buildings within the sample-area were mostly free-standing duplexes and multi-user dwellings. Other building types within close proximity were detached and semi detached bungalows on one hand and 'compoundtype' or tenement buildings with many rooms and a single entrance. Table 1 below shows household sizes and frequency of occurrence in the case study area.

Table 1: Household Size Distribution of Jabi-District, Abuja

\begin{tabular}{lll}
\hline Household Size & Frequency & Percentage \% \\
\hline $\begin{array}{l}\text { One person/ } \\
\text { household } \\
\begin{array}{l}\text { Two persons/ } \\
\text { household }\end{array}\end{array}$ & 28 & 13.1 \\
$\begin{array}{l}\text { Three persons/ } \\
\text { household }\end{array}$ & 51 & 20.2 \\
$\begin{array}{l}\text { Four persons/ } \\
\text { household }\end{array}$ & 44 & 20.7 \\
$\begin{array}{l}\text { Five persons+/ } \\
\text { household } \\
\text { Total }\end{array}$ & 47 & 22.1 \\
\hline
\end{tabular}

Table 1 above shows and describes household size in the sampled areas: $13.1 \%$ of the respondents were households comprising of one person, $20.2 \%$ respondents indicated having a size of two persons per household, $23.9 \%$ responses were from residences with three persons per household, $20.7 \%$ of responses were from residences with four persons per household, whilst $22.1 \%$ of respondents indicated five+ persons per household as their population size. 
Integrated Solid Waste Management.................MATON et al.

Waste Generation and Disposal

Table 2: Rate of Waste Generation per Household in Jabi-District, Abuja

\begin{tabular}{lll}
\hline $\begin{array}{l}\text { Household Waste Collection } \\
\text { Assessment-Rate of waste generation. }\end{array}$ & Frequency & Percentage \% \\
\hline 1- 2 days & 41 & 19.2 \\
3- 5days & 93 & 43.7 \\
1 week & 79 & 37.1 \\
Total & 213 & 100 \\
\hline
\end{tabular}

Table 2 above shows the waste generation rate per household, in the case study area. The rate of waste generation is deduced from a sample of randomly distributed 160 gauge polythene waste collection bags to households and observation carried out on how long it takes those bags to be filled and disposed of in the public dumps. $19.2 \%$ of the respondents observed that it took them 12 days to have their waste bags filled up; $43.7 \%$ observed that it took them 3- 5 days while $37.1 \%$ observed that it actually took them 1 week to have their bags filled up before they disposed of the waste. Over the period of the study, an average weight of $15.6 \mathrm{~kg}$ of domestic waste was generated per household.

Table 3: Methods of Waste Disposal in Jabi-District, Abuja

\begin{tabular}{lll}
\hline Methods of Waste disposal & Frequency & Percentage \% \\
\hline Collected in dustbins & 42 & 19.7 \\
Buried by households/ composting & 29 & 13.6 \\
Public dump & 116 & 54.5 \\
Dumped elsewhere/ incineration & 19 & 8.9 \\
Burned elsewhere & 7 & 3.3 \\
Total & 213 & 100 \\
\hline
\end{tabular}

From Table 3 above, $19.7 \%$ of the respondents collect their waste in dustbins, $13.6 \%$ bury their waste, and $54.5 \%$ use the public dumpsite, $8.9 \%$ dump their waste elsewhere, while $3.3 \%$ burn their waste causing air pollution to the atmosphere.

Table 4: Methods of Waste Disposal in Jabi-District, Abuja

\begin{tabular}{lll}
\hline $\begin{array}{l}\text { Do you usually sort your waste into different } \\
\text { waste disposal bags? }\end{array}$ & Frequency & Percentage \% \\
\hline Yes & 0 & 0 \\
No & 213 & 100 \\
Total & 213 & 100 \\
\hline
\end{tabular}

Table 4 above shows total population for the questionnaire administration and indicated that none of the respondents sorted their waste into categories before disposing; majority of the population just discard their waste in the dumpsters, without sorting into biodegradable and non-biodegradable components. Therefore this goes to say poor waste management emanates from the households. Research has proven that an important element in efforts to deal with 
waste is a clear consumer perspective. Research also indicates that volumes of waste in urban centers are increasing in line with economic growth.

Table 5: Methods of Waste Disposal in Jabi-District, Abuja

\begin{tabular}{lll}
\hline Who normally dispose of the waste & Frequency & Percentage \% \\
\hline Father & - & - \\
Mother & 27 & 12.7 \\
Children & 63 & 29.6 \\
House- help & 123 & 57.7 \\
Total & 213 & 100 \\
\hline
\end{tabular}

Table 5 indicates respondents' opinion on those to whom the task of disposal of household waste is saddled, in the survey area. $12.7 \%$ of respondents opined that mothers are responsible; $29.6 \%$ indicated that children are more involved; whilst $57.7 \%$ were of the opinion that household waste in their neighborhood was disposed of by house- helps. It can thus be deduced that the responsibility of waste disposal is largely saddled with children and house-helps. By this, it is clear that indiscriminate dumping should be expected since the adult and or mature age bracket is hardly involved in disposal of the household wastes.

Access to Waste Management Service Providers

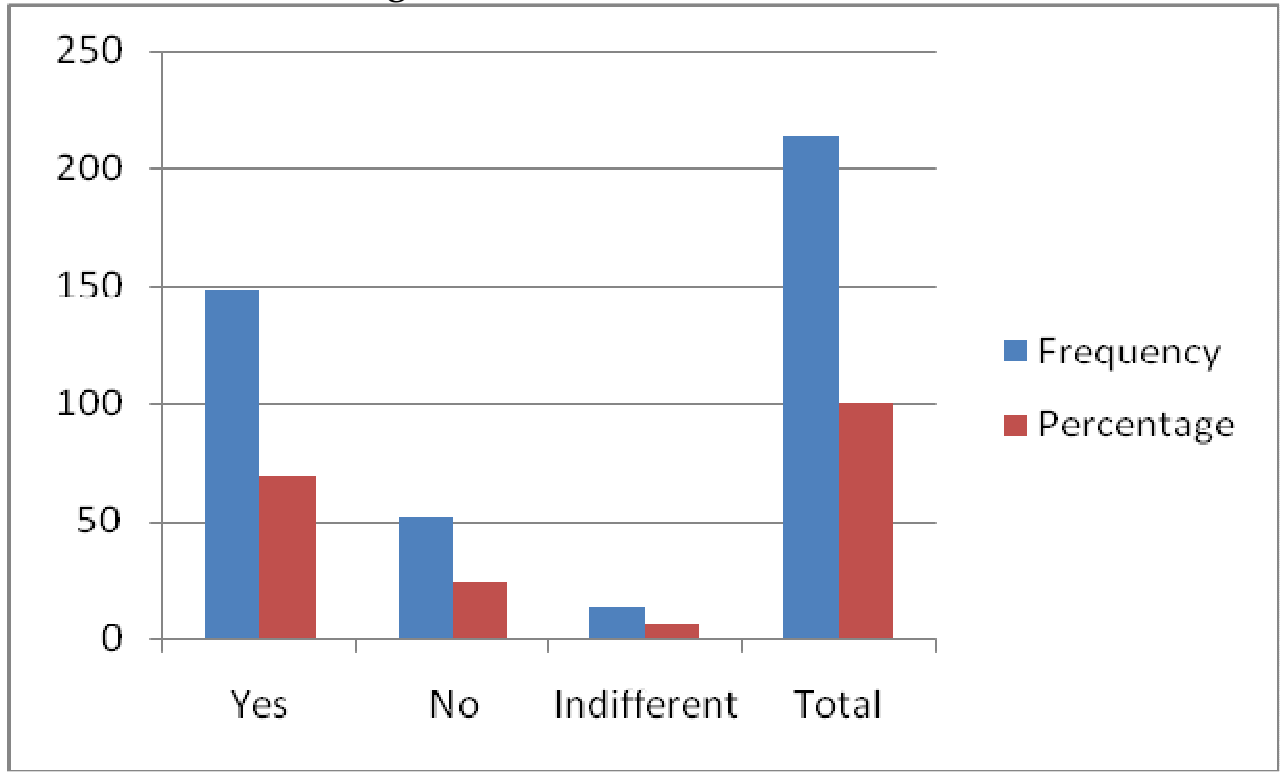

Figure 3: Presence of Service Providers

The above figure explains respondents' views on service providers for collection and transportation of waste from the study area. $69.5 \%$ attest to the presence of a waste 
management service provider, $24.4 \%$ declines the existence of such services whilst $6.1 \%$ indicated indifference or uncertainty of waste service providers in their neighborhood.

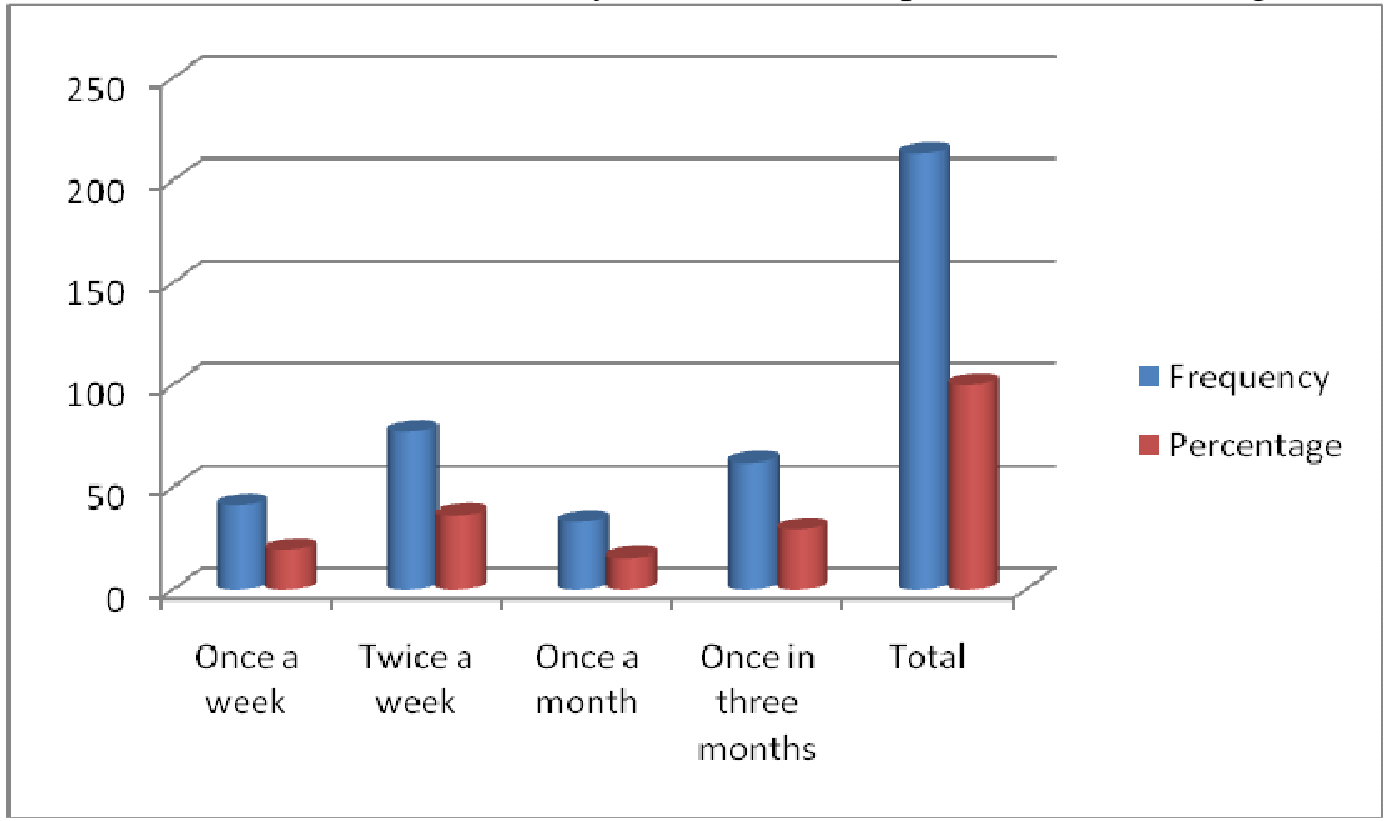

Figure 4: Frequency of waste evacuation

From the above graphical presentations, $19.2 \%$ of respondents attested to once a week collection of waste by service providers, $36.2 \%$ indicated that waste was collected twice a week $15.5 \%$ attested to a routine of oncea- month whilst $29.1 \%$ indicated once-inthree-months as intervals of waste collection.

Without proper or frequent waste management practices, people are more likely to suffer from environmental health- related diseases. These can sometimes be fatal. Based on physical assessment during the survey, the waste disposed of constitutes a lot of problems on the roads especially during the raining seasons. Aside being an eyesore, the stench of smell emanating from the dumpsters and waste collection processes which is dangerous to the inhabitants of the community.
This study established that the routine collection of wastes is done during the day and is often characterized by offensive odors from the waste collections vehicles plying through the metropolis.

General Hygiene Knowledge of Waste Management in the Area

Sanitation is the hygienic means of promoting health through prevention of human contact with the hazards of wastes. Hazards can be physical, microbiological, biological or chemical agents of disease. Wastes that can cause health problems are human and animal feaces, solid wastes, domestic wastewater (sewage, sullage, grey water), industrial wastes and agricultural wastes. Ideally communities like the sampled area are well planned but there are unplanned settlements at the fringes who also contribute to poor waste management practices in the area. 
Table 6: Respondents' Views on Effectiveness of Waste Management Services

\begin{tabular}{lll}
$\begin{array}{l}\text { Will you say the waste management system by the } \\
\text { government is yielding results }\end{array}$ & Frequency & Percentage \% \\
Yes & 152 & 71.4 \\
No & 61 & 28.6 \\
Total & 213 & 100 \\
\hline
\end{tabular}

Table 6 shows the opinion of respondents on the effectiveness of waste management services in the sample area. $71.4 \%$ of respondents affirmed the effectiveness of waste collection service providers to the overall wellbeing of residents and the environment while $28.6 \%$ were of the opinion that government's effort at management municipal solid waste was not effective.

\section{Conclusion and Recommendations}

Solid waste management has to do with the handling of solid refuse, from the point of generation through storage, collection, transportation, recovery and treatment processes to disposal. The poor management of these wastes poses a great danger not only in polluting the environment but to human well-being as well. From the findings of this study, $15.6 \mathrm{~kg}$ of waste was generated per household per week in the case study area. With an average of 3 persons per household, the waste generation translates into $0.74 \mathrm{~kg} / \mathrm{capita} /$ day, which is higher than the $0.71 \mathrm{~kg} /$ capita/day generated in Ibadan, Oyo State and the general average of $0.58 \mathrm{~kg} / \mathrm{capita} /$ day in other Nigerian cities (Babayemi and Dauda, 2009). 19.2\% of respondents alluded to an evacuation pattern of once a week in their neighborhoods; $36.2 \%$ of respondents attested to twice a week; $15.5 \%$ indicated once a month whilst $29.1 \%$ attested to once in three month evacuation by service providers. In spite of the disparity of collection, the results confirm the presence of waste collection services in the case study area. However, the disparity in frequency of waste evacuation may not be unconnected to the land use orientation in the study area, where some of the carved out units were planned and easily accessible to service providers, while other units were unplanned and less accessible. A conspicuous result of infrequent waste collection is evident in the heaps of refuse and garbage commonly found on some of the streets of the study area, most especially the unplanned neighborhoods. The study also revealed the lack of Integrated Solid Waste Management System evident by the $100 \%$ response to non-sorting of wastes generated from households. This agrees with the findings of Otitoju (2014) that the solid wastes collected from the streets of Nigerian urban centres are dumped in the open dumps without due recourse to sorting at source of waste generation and disposal.

From the foregoing it is obvious that the waste management challenge in Nigeria can be attributed to the wrong attitude of the public, poor planning as a result of lack of will to do the right thing and lack of legal framework and enforcement of existing regulations as aptly elucidated by previous researches by Ogwueleka, 2009; Abila and Kantola, 
2013; Olukanni et al., 2014. It is therefore the authors' opinion that Integrated Solid Waste Management practices and principles of sorting of waste at source of generation would reduce the adverse impacts on human health while eliminating the effects on the environment through waste reduction, reuse and recycling (3Rs).

\section{Recommendations}

The authors wish to make the following recommendations as palliatives to the solid waste management challenges in Jabi district in accordance with best practices:

$>$ Refresher courses and neighbourhood awareness campaigns on regular basis. For instance, public awareness should be encouraged on best ways to manage waste from primary to secondary schools. They are considered best agents of change;

$>$ Effect an Integrated Solid Waste Management System for Jabi Ditsrict and its environs where generation, collection and disposal of solid waste is done with sustainability and/or best practices in mind;

Improve on infrastructure i.e procurement of waste evacuation vehicles and proper landfill designs to dispose of the solid waste rather than open dumping;

Improve on workers remuneration and incentives and provision of safety wares for routine waste collection works;

Consider a change in schedule of waste collection to night-time or early mornings due to foul odour of refuse;

Enforce punitive measures side by side the existing laws protecting the environment on defaulters who indiscriminately throw refuse on the streets and open fields.

\section{Acknowledgement}

The authors wish to acknowledge the contributions of the NBRRI Environment and Climate Change Research Group [NBRRI-ECCRG] and to state that this is part of a larger (ongoing) research project funded by the Nigerian Building and Road Research Institute (NBRRI). The magnanimity of the Director General/ CEO Professor Danladi S. Matawal and the Management Staff is here acknowledged and appreciated.

\section{References}

Abel, O.A. (2009). An Analysis of Solid Waste Generation in a Traditional African City: The Example of Ogbomoso, Nigeria. Environment and Urbanization SAGE Journals 19(2): 527-537.

Abila, B. and Kantola, J. (2013). Municipal Solid Waste Management Problems in Nigeria: Evolving Knowledge Management Solution.

Agbesola, Y. (2013). Sustainability of Municipal Solid Waste Management in Nigeria: A Case Study of Lagos.

Babayemi, J.O. and Dauda, K.T. (2009). Evaluation of Solid Waste Generation, Categories and Disposal Options in Developing Countries: A Case Study of Nigeria. J. Appl. Sci. Environ. Manage., 
13(3): 83 - 88. Available online at http://www.bioline.org.br/pdf?ja090 $\underline{42}$

Fermanich, J. (2014). Safety and Environmental Management, University of Wisconsin-Green Bay, Available online at www.uwgb.edu.

Geoffrey, I.N. (2005). The Urban Informal Sector in Nigeria: Towards Economic Development, Environmental Health and Social Harmony. Global Urban Development Magazine 1 (1).

Leton, T.G. and Omotosho, O. (2004). Landfill Operations in the Niger Delta Region of Nigeria. Engineering Geology, 73(1-2): 171177.

Mshelia, A.D. (2015). Solid waste management: An urban environmental sanitation problem in Nigeria. Sky Journal of Soil Science and Environmental Management, 4(3): 034 - 039. Available online http://www.skyjournals.org/SJSSE

M ISSN 2315-8794@ 2015 Sky Journals.

Ogwueleka, T.C. (2009). Municipal Solid Waste Characteristics and Management in Nigeria. Iran. $J$. Environ. Health Sci. Eng., 6(3): 173-180.

Olukanni, D.O., Akinyinka, O.M., Ede, A.N., Akinwumi, I.I. and Ajanaku,
K.O. (2014). Appraisal of Municipal Solid Waste Management, its Effect and Resources Potential in a SemiUrban City: A Case Study. J. of South African Business Res., 1-13.

Onibokun, A.G. and Kumuyi, A.J. (1996). Urban Poverty in Nigeria: Towards Sustainable Strategies for its Alleviation. Center for African Settlement Studies and Development, Ibadan, Nigeria. CASSAD Monograph Series 10.Pp.1-2.

Onyanta, A. (2005). The Spatiality of Governance: Social Spaces and Privatization of Solid Waste Services in Abuja, Nigeria. Accessed online http://naerus.net/web/sat/workshops/2005/ papers/9.pdf

Otitoju, T.A (2014). Individual Attitude toward Recycling of Municipal Solid Waste in Lagos, Nigeria. American Journal of Engineering Research (AJER), 3(7): 78-88 eISSN : 2320-0847 p-ISSN : 23200936 www.ajer.org.

Wahab, W.B. (2012). Solid Waste: Issues and Challenges in Urban Context, PowerPoint format retrieved from the internet $5^{\text {th }}$ August 2014. 